\title{
Innovation and value in pre-commercial procurement
}

A systematic evaluation of national experiences

Brogaard, Lena

Published in:

Journal of Strategic Contracting and Negotiation

DOI:

$10.1177 / 2055563618799065$

Publication date:

2017

Document Version

Peer reviewed version

Citation for published version (APA):

Brogaard, L. (2017). Innovation and value in pre-commercial procurement: A systematic evaluation of national experiences. Journal of Strategic Contracting and Negotiation, 3(3), 1-20.

https://doi.org/10.1177/2055563618799065

\section{General rights}

Copyright and moral rights for the publications made accessible in the public portal are retained by the authors and/or other copyright owners and it is a condition of accessing publications that users recognise and abide by the legal requirements associated with these rights.

- Users may download and print one copy of any publication from the public portal for the purpose of private study or research.

- You may not further distribute the material or use it for any profit-making activity or commercial gain.

- You may freely distribute the URL identifying the publication in the public portal.

Take down policy

If you believe that this document breaches copyright please contact rucforsk@kb.dk providing details, and we will remove access to the work immediately and investigate your claim. 
Innovation and value in pre-commercial procurement: A systematic evaluation of national experiences

\begin{abstract}
Governments increasingly use novel forms of public procurement to stimulate innovation in public service delivery. A notable example is pre-commercial procurement (PCP). Launched by the European Commission a decade ago, PCP encourages research and development of new solutions for the public sector. However, limited theoretical and empirical studies have made it difficult to assess and improve use of the model to foster public innovation. Based on two PCP projects in Denmark, the article aims to complete the first systematic and theory-based evaluation of national experiences. The evaluation shows that sufficient resources, participant and management commitment, and focused governance of the innovation process contributed to successful development and testing of a new solution in one of the projects. Meanwhile, technical obstacles in developing a prototype resulted in termination of the other project. In this case, the PCP model cannot accommodate significant changes to the agreed solution during the innovation process.
\end{abstract}

\title{
Introduction
}

The use of public procurement policies as a tool for innovating public services has become increasingly prominent within the EU and its member states (Petersen et al., 
2016; Rolfstam, 2009). Innovation procurement utilizes the expertise of the private sector to support the development of new solutions by signaling to the market what is currently in demand in the public sector (Lember et al., 2011; Chicot and Matt, 2017). The very idea underlying this trend is to target products and services that are not 'off the shelf' and share the technological risks between purchaser and supplier (Edler and Georghiou, 2007). A notable example of this idea is pre-commercial procurement (PCP), which the European Commission adopted a decade ago (European Commission, 2007). PCP purchases the development of new services and solutions to specific problems not yet addressed in the market (Rainville, 2017). Although PCP is exempt from EU procurement rules and excludes commercialization, the intention is to de-risk the usually uncertain technological development and provide a more sound foundation for commercialization, thereby increasing the likelihood of innovation (Edquist and Zabala-Iturriagagoitia, 2015; Rainville, 2017). In comparison, public procurement of innovative solutions is likewise an innovation policy instrument which - as opposed to PCP - aims to diffuse already invented solutions rather than encourage the development of new (see Table 1) (Edquist and Zabala-Iturriagagoitia, 2015; European Commission, 2017). 
Table 1 Differences between innovation procurement models

\begin{tabular}{|c|c|c|}
\hline & $\begin{array}{l}\text { Pre-Commercial } \\
\text { Procurement }\end{array}$ & $\begin{array}{l}\text { Public Procurement of } \\
\text { Innovative solutions }\end{array}$ \\
\hline Purpose & $\begin{array}{l}\text { The purpose is to purchase } \\
\text { development of new solutions. }\end{array}$ & $\begin{array}{l}\text { The purpose is to diffuse and } \\
\text { adopt innovative solutions. }\end{array}$ \\
\hline $\begin{array}{l}\text { Public sector } \\
\text { rationale }\end{array}$ & $\begin{array}{l}\text { The public actor encourages } \\
\text { research and development into } \\
\text { new solutions that can address } \\
\text { demands and challenges in the } \\
\text { public sector. }\end{array}$ & $\begin{array}{l}\text { The public actor encourages } \\
\text { companies to produce more of } \\
\text { a developed solution (not yet } \\
\text { available in large scale), which } \\
\text { is needed in the public sector. }\end{array}$ \\
\hline $\begin{array}{l}\text { Model } \\
\text { implementation }\end{array}$ & $\begin{array}{l}\text { The public actor(s) compare } \\
\text { possible solutions proposed by } \\
\text { businesses to identify the best } \\
\text { suited through design and } \\
\text { prototype development phases. } \\
\text { It is based on risk-benefit } \\
\text { sharing, competition, and } \\
\text { separation from the } \\
\text { commercial phase. }\end{array}$ & $\begin{array}{l}\text { The public actor(s) announce } \\
\text { certain innovation needs and } \\
\text { purchases the best suited } \\
\text { solution. This process can be } \\
\text { the result of a PCP, while the } \\
\text { actual purchase takes place } \\
\text { through existing procurement } \\
\text { procedures. }\end{array}$ \\
\hline
\end{tabular}

Source: (European Commission, 2017; Edquist and Zabala-Iturriagagoitia, 2015)

In recent years, we have witnessed an upsurge in studies on public procurement for innovation. Scholars are exploring drivers and barriers (Uyarra et al., 2014; Smith et al. 2018), the influence of spatial anchoring (Uyarra et al., 2017), risk management (Kalvet and Lember, 2010), the role and characteristics of public procurement in fostering innovation (Edquist and Zabala-Iturriagagoitia, 2012; Chicot and Matt, 2017; Raiteri, 2018), and innovation in contracting practice (Timmer, 2016). Meanwhile, PCP studies are scarce with the exception of a few contributions that question whether PCP is even a policy instrument for innovation, as it is oriented toward the supply-side and supports the early phases of innovation (Edquist and Zabala-Iturriagagoitia, 2015; 
Askfors and Fornstedt, 2018; Rainville, 2017). As a result, national experiences with PCP have yet to be scrutinized and systematic evidence is needed to assess the use and effectiveness of PCP in spurring innovation. The limited research on PCPs and innovative procurement leaves a theoretical and empirical gap in terms of how and under what circumstances public procurement leads to innovation and benefits the public and private sectors.

The broader aim of this article is to complete the first systematic and theory-based evaluation of national experiences with the PCP model known to the author. The article provides insights into drivers and barriers in applying the PCP model and the first empirical evidence of whether PCP facilitates the development of new solutions and creates value for the public and private partners. Due to the limited empirical and theoretical knowledge on this topic, there are no clear expectations regarding drivers and barriers to PCP to guide this study. To develop a theoretical framework, the article applies a program theory approach to identify which key factors facilitate a successful PCP process based on both general assumptions from formal theories and empirical data (Chen and Turner, 2012; Funnel and Rogers, 2011). The theoretical framework thus implements and takes the particular empirical context into consideration (Pitsis, 2015). This approach results in a focus on three analytical levels of structural, collaborative process, and participant factors that revolve around the legal framework, the interaction among the partners, and the characteristics of the participants. The overall aim and 
theoretical approach leads to the following research question: How do participant, collaborative process, and structural factors constrain or drive the development of new solutions and value creation in pre-commercial procurement?

The article addresses the research question through an evaluation of a Danish PCP initiative. In Denmark, policy-makers have paid increasing attention to the potential in innovative public procurement (Rolfstam and Petersen, 2014). In 2014, the Danish Market Development Fund (MDF) - in partnership with the five regional governments in Denmark - launched two PCP projects with the purpose of promoting innovative and effective solutions to two cross-hospital challenges. The Danish case thereby constitutes a unique opportunity to evaluate national experiences with PCP. One of the projects revolves around the development of an automated and efficient hospital sterilization center, where there is no risk for contamination of instruments (Sterile PCP). The purpose of the other PCP project is to develop a solution that minimizes contagion in hospital rooms and thereby reduces the risk of infection in patients (Contagion PCP). The two PCP projects use identical procurement processes to find and select relevant businesses. The projects consist of two phases, of which the first entails the development of a concrete design proposal, while the second phase revolves around developing and testing a functional prototype (The Danish Market Development Fund, 2014a; The Danish Market Development Fund, 2014b). The evaluation of the two cases is a longitudinal study, which provides insights into what is often the 'black box' of 
innovative procurement processes. Based on project documents and interviews with participants collected at two points in time, the longitudinal design makes it possible to study the development of key drivers and barriers over the course of two years.

The paper proceeds as follows. The next section presents the theoretical framework, followed by an introduction to the research design and methods in section three. The analysis in section four evaluates the two phases of each PCP case, focusing on identifying which factors drive or constrain the development of new solutions and value creation. Finally, in section five, the paper discusses and compares the role of key structural, collaborative, and participant factors across both cases before concluding on the findings and implications for further research.

\section{Theoretical framework: PCP program theory}

The program theory approach to developing a theoretical framework clarifies the underlying assumptions of how to develop new solutions and create value for the public and private partners. Developing program theory using existing research and empirical data is an iterative process. The two sources support and supplement one another in identifying which factors lead to innovation and value creation. The purpose is to analyze if these key factors are implemented according to the program theory and with what consequences (Vedung, 2009). The advantage is that program theory takes the empirical context of the Danish case into consideration but still provides a more general framework by drawing on formal theories and existing research. Specifically, the 
theoretical framework in this study combines formal theories on networks and systems of innovation with empirical data from the Danish case (Chen and Turner, 2012; Funnel and Rogers, 2011).

The empirical foundation of the framework comprises procurement documents and contracts from the Danish case that provide information on the formal requirements, outcomes, and management of the PCP. The theoretical framework is based on the PCP projects' two phases and intended outcomes. In phase I, the public actors enter an agreement with qualified suppliers based on their proposed solutions to address the needs described in the tender. They have six months and a limited fee to develop a more concrete design proposal. Based on the specified design proposals, the public actor then selects businesses from phase I to continue into phase II, where a larger fee is allocated for testing and developing prototypes. Both phases depend on exchange of knowledge and expertise between participating businesses and healthcare professionals. The two projects vary only in their focus on addressing different needs within the hospital sector (Kammeradvokaten, 2014a; Kammeradvokaten, 2014b). The organization of both cases consists of a high-level steering committee with representatives from the five Danish regions that initially decided to launch the PCP projects and a secondary steering group established to oversee the contracts and project development. Meanwhile, the main forum for the collaboration and innovation process is a reference group for each PCP, which is in charge of the communication and exchange of knowledge among the public 
and private participants. Reference group members include healthcare professionals with relevant expertise, representatives from the businesses, and an MDF representative.

The theoretical foundation of the framework draws from formal theories on systems of innovation and network governance. These theories posit what drives the facilitation and informal governance of a network among interdependent public and private participants within a predetermined structure (Lundvall, 2010; Provan and Kenis, 2008). The theoretical perspectives shed light on which factors are key to a successful process in the Danish case and categorize these factors into a multi-level framework of structural, collaborative process, and participant factors. The subsequent sections elaborate on each of these analytical levels of the theoretical framework based on the formal theories and case documents. Figure 1 illustrates the final framework toward the end of this section.

\section{Structural factors}

The first level of factors stems in part from innovation system theory, which focuses on how innovation processes take place within a larger national system of networks and institutions. As a part of this system, public agencies fulfill an important role in spurring (or inhibiting) innovation through policy-making and regulation (Lember et al., 2011; Lundvall, 2010). PCP is an example of this role. The PCP model structures the innovation process through a pre-determined procurement process and contract. In the Danish case, the PCP model entails two phases with different purposes, a fixed budget, 
and specified regulation with which the design proposal and prototypes must comply to ensure risk and benefit sharing on market conditions (The Danish Market Development Fund, 2014a; The Danish Market Development Fund, 2014b; Kammeradvokaten, 2014b). Moreover, the PCP model presumes participation of several suppliers meant to stimulate the businesses' efforts to develop the best possible solution (Kammeradvokaten, 2014a; The Danish Market Development Fund, 2014e; Kammeradvokaten, 2015a). Through competition, the public partner chooses the best partner and creates an incentive for the businesses to improve the quality and reduce the cost of the task (Andrews and Entwistle, 2015). A final key structural component, originating in the project documents, concerns the importance of resource munificence. In the Danish PCP case, the selected firms are partly compensated for their work to facilitate the development of solutions which might not otherwise have been developed (Kammeradvokaten, 2014b; Kammeradvokaten, 2015b). Network theory supports the importance of this factor, as sufficient funding, hours, and staff is expected to have a positive impact on outcomes (Raab et al., 2015).

\section{The collaborative process}

The second analytical level of factors draws on network theory and concerns the collaborative process among different actors participating to gain access to each other's resources and expertise (Provan and Kenis, 2008). This perspective is highly relevant for PCP, where business and public representatives interact within the reference groups 
to engage in an exchange of knowledge and learning. According to network theory, collaboration is not without difficulties as the partners represent different organizational cultures, values, interests, and rules, which can lead to conflict (Klijn et al., 2015). Hence, relationships based on mutual trust are assumed to increase the likelihood of successful outcomes (Edelenbos and Klijn, 2007; Klijn et al., 2016). Although trust is not an explicit focus in the Danish PCP documents, they do emphasize trust and communication as collaborative mechanisms to ensure a focused innovation process and avoid conflicts (The Danish Market Development Fund, 2014d). Theories of innovation systems furthermore point to knowledge and learning as the core of innovation processes (Edquist and Hommen, 1999; Lember et al., 2011). A similar underlying notion is found in the case documents. The reference groups ensure representation of the most relevant public healthcare professionals across the country and the selected businesses, who can exchange knowledge in order to develop the most appropriate design proposal and prototype (The Danish Market Development Fund, 2014d).

\section{Participants}

The final level of factors to include in the theoretical framework revolves around the participating individuals, groups, and organizations that influence the agenda (Huxham and Vangen, 2000). Network theory assumes that overcoming institutional differences and facilitating learning and the exchange of knowledge requires some form of network management by initiating and facilitating interaction among the network members 
(Klijn et al., 2010). This role can be the responsibility of a lead organization or the participants themselves through informal, shared governance (Provan and Kenis, 2008). In the context of the Danish PCP project, the procurement documents and contracts emphasize the importance of MDF as the designated project management (Kammeradvokaten, 2015b). Moreover, network theory posits that successful outcomes are dependent upon the competencies and commitment of the participants. Relevant skills and resources to deal efficiently with the task or problem at hand increase the likelihood of success (Nohrstedt, 2016; Provan and Kenis, 2008). The contracts and procurement documents show that within the reference groups, collaboration between healthcare professionals with relevant expertise and the involved businesses is expected to foster innovation (The Danish Market Development Fund, 2014d). Moreover, the contract commits the businesses to ensuring that their own representatives have the necessary skills and knowhow (The Danish Market Development Fund, 2014d; Kammeradvokaten, 2014b).

\section{Development of new solutions and value creation}

The final component of the theoretical framework concerns the outcomes of the PCP. Overall, the two Danish PCP projects aim to develop new, innovative solutions to reduce contagion in hospital rooms and contamination of instruments respectively (The Danish Market Development Fund, 2014a; The Danish Market Development Fund, 2014b). More specifically, the procurement documents state that up to five suppliers can 
participate in the first phase to develop a design proposal that identifies the technical and commercial potential, which constitutes the outcome in phase I (Kammeradvokaten, 2014a). The public partner then selects two to three suppliers to develop and test a functional prototype of the selected design proposals as the main outcome in phase II, as PCP does not entail commercialization of the developed solution (Kammeradvokaten, 2015a). The intention is to separate the innovation process from the commercial phase in PCP to make it possible for the public partner to acquire knowledge and compare test evidence before committing to a large investment (European Commission, 2007). The program theory further examines the types of benefit the public and private actors gain, as the underlying rationale is that public-private collaboration creates positive outcomes that the partners could not achieve by themselves (Steijn et al., 2011). Based on initial interviews with public and private representatives, a successful PCP process is expected to produce benefits for their organizations, such as access to new markets, new knowledge, contacts for future use and reference, and experience with new forms of innovative procurement.

Figure 1 illustrates the program theory and factors expected to influence the development of new solutions and value creation in both phases. 
Figure 1 Program theory for phase I and II of the PCP study

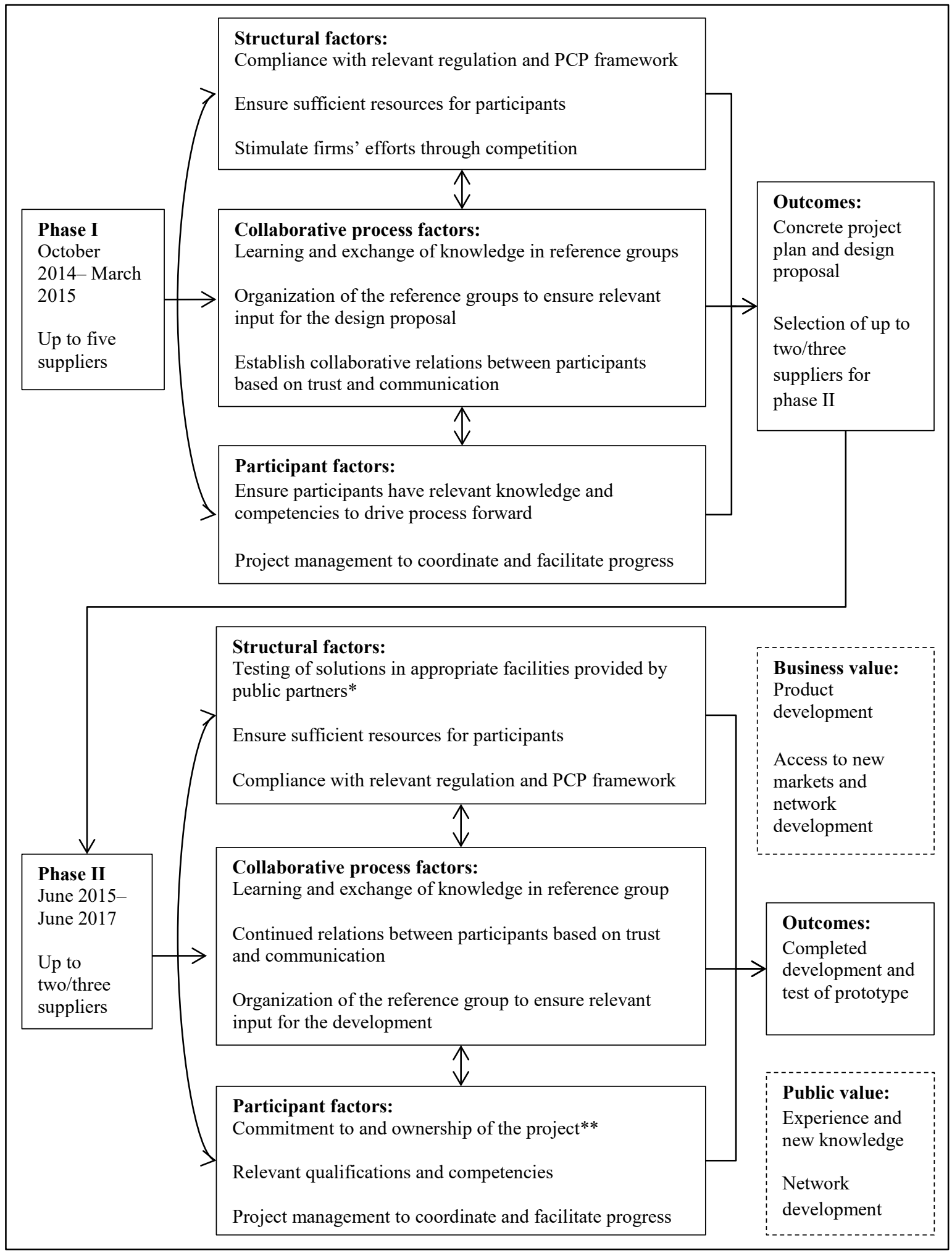

Sources: Author's own based on project documents and the applied theory

* Only relevant for development and testing in phase II/**Factor added based on evaluation of phase I 


\section{Research design and methods}

The longitudinal study uses two types of data collected at two points in time to evaluate developments in drivers and barriers and to gain insights into the procurement and collaborative process. The first type of data consists of tender documents from both phases (description of needs, competitive conditions, and contracts). The documents provide information concerning the criteria for selecting businesses, the budget and formal framework for the collaborative process, and the purpose of the PCP. The second type of data is semi-structured interviews with 16 key participants from the two PCP projects, representing the involved businesses, public reference group members, and the MDF project management. Eight of the 16 participants were interviewed twice - at the end of phase I (Fall 2015) and toward the end of phase II (Winter 2016/2017) — due to their continuous participation. The other eight were interviewed at one of these points in time as they either left the project after phase I or joined in phase II. ${ }^{1}$

The semi-structured interviews gained information about the participants' perceptions of key factors and goals. The semi-structured approach was chosen to leave room to follow up on new findings, while still guiding the interviews based on the program theory. All interviews thus used an interview guide consisting of open questions that enquired about the participants' expectations, motivation to participate, perception of outcomes, drivers and challenges, and how the participants addressed these challenges. 
Data analysis was completed in three steps. First, interview transcripts and documents were continuously coded throughout the evaluation to identify drivers and barriers. $^{2}$ The coding was based on a deductive coding scheme developed from the theoretical framework. The interview transcripts and documents were segmented into coding units referring to specific structural, collaborative process, or participant factors. In additional, valence codes characterized whether the given factor was perceived as a driver or a challenge by the interviewees (Miles and Huberman, 1994). For instance, an interview segment concerning an interviewee's perception of the relationships, dialogue, and meetings between participants was coded as related to trust and part of the collaborative process. Second, to gain an overview of which factors influence the PCP, relational matrices compared which theoretical factors were coded primarily as drivers or challenges, studying the coded interview segments for further details and narratives. Finally, case dynamics and causal network displays (see Figures 2 and 3 in the analysis) compared and illustrated patterns in the two projects for each phase in terms of which key structural, collaborative process, and participant issues have either enhanced or inhibited the creation of new solutions and value (Miles and Huberman, 1994).

The assessment of outcomes is partly based on the public partners' formal scoring of businesses' performance in the procurement documents, which expresses to what degree the businesses' design proposals meet the agreed specifications and public partners' requirements (Kammeradvokaten, 2015a; The Danish Market Development 
Fund, 2014a: 15-16). Moreover, the assessment uses the public and private participants' perception of and satisfaction with the developed prototype, completed tests, and the benefits they have gained (or not). Perceived outcomes are often considered a less than ideal form of measurement. However, in this case, it is highly relevant to ask the participants themselves what they have gained from the PCP and to acknowledge that there is more than one legitimate criterion by which to assess performance in a network (Edelenbos et al., 2011; Kenis and Provan, 2009). The evaluation of the second phase is completed a few months before the two-year second phase is scheduled to end, which means that it will be an assessment of the expected or achieved outcomes at the time. ${ }^{3}$

\section{Analysis of the two PCP projects}

The subsequent sections analyze the drivers, barriers, and outcomes in phase I and phase II for each PCP project. The empirical results are then discussed across the two projects in the light of the theoretical framework and PCP model.

\section{Sterile PCP}

\section{Phase I}

In collaboration with the reference group, the MDF selected two businesses to participate in sterile PCP based on the initial tender for the project. The first phase was characterized by challenges to the exchange of knowledge in the reference group due to a limited number of public representatives with insufficient resources to participate. The healthcare professionals in the reference group found it difficult at times to provide 
input and collaborate with the businesses alongside their normal jobs. Based on the PCP contract, the public partners were obligated to put their knowledge and test facilities at the project's disposal (Kammeradvokaten, 2014b). These were terms accepted by the steering committee that initiated the PCP project and appointed the public members of the reference group. The implication was that the PCP did not compensate the reference group members, who had to find time within their normal work hours to participate. This challenge resulted in some members exiting the project, while others left due to job changes, meaning that only a few public representatives remained to collaborate with the businesses.

Because of the reduced reference group, there was only limited interaction and exchange of knowledge between the businesses and the healthcare professionals (phase I interview with nos. 9 and 11). As one of the businesses explained, the remaining reference group members were always committed to help, but too much time would pass before they could actually provide feedback and there were not enough face-to-face meetings to get the necessary input (phase I interview with no. 7). Instead, the project became dependent upon stronger formal leadership by the MDF, which became a key driver in phase I. The MDF worked to keep the project moving forward, thus spending a lot more time and resources on managing the PCP than anticipated (phase I interview with nos. 13 and 14). 
Despite these challenges, phase I outcomes were to some degree achieved. The two companies developed and submitted concrete design proposals in an updated tender for phase II. However, they spent markedly more time and resources on it than expected in order to contact and meet hospital representatives outside the reference group to ensure sufficient input (phase I interview with nos. 7 and 12). From the public partner perspective, the selection of businesses for phase II was completed, but only two businesses participated in phase I in sterile PCP of which the MDF selected one to continue to phase II. Moreover, the MDF and the few remaining reference group members were in charge of evaluating the proposals. Although aided by a law firm with procurement competencies, they experienced the task of choosing the most relevant and innovative solutions as a big responsibility (phase I interview with nos. 9 and 14).

\section{Phase II}

In phase II, the development and testing of prototypes based on the selected business' design proposal was constrained by the continued presence of challenges from phase I and the emergence of new obstacles. It remained difficult for the reference group members to find and prioritize enough time to deliver input for the business's internal testing and development. Despite additional members to the group, it consisted of a limited core of committed members (phase II interview with nos. 8, 10, and 11). Although all parties perceived the collaborative relationship as productive and trusting, the participating business' expectations of and reliance on the reference group for all 
types of input exceeded the group's resources (phase II interview with nos. 8, 10, 11, and 13).

Part of the challenge of ensuring sufficient and committed members in the reference group can be ascribed to limited support from the top-level regional management in the steering committee who initiated the PCP, and lack of awareness of the project in the participating organizations and hospitals. Without management commitment, the division of funding and responsibilities was unclear, in turn leaving the reference group unsure of who should take care of what and with what resources (phase II interview with nos. 10, 11, and 13). The formal project management by the MDF attempted to ensure progress and continued to be an important driver. However, the MDF was dependent upon the expertise of and collaboration between the reference group and the business to develop and test the prototype.

Moreover, at the beginning of the second phase, the PCP faced a new obstacle of finding test facilities. Due to the innovative purpose of the PCP tender, there was no specified solution at the onset, and the PCP contract did not specify the test facility or whom should provide it. The regional governments and the MDF eventually allocated resources to help resolve this issue early on in the second phase and the public partners suggested possible locations (phase II interview with no. 13). However, before suitable test facilitates were decided on, a new challenge emerged concerning the business' development of a prototype. The reference group members had questioned the progress 
and lack of demonstration of a prototype during meetings with the business, which had admitted to delays and technical difficulties. However, half way through phase II, the business disclosed that the technological development required for the most innovative — and, to the public partner, most relevant—part of the design proposal was not feasible within the PCP timeframe (phase II interview with nos. 8, 10, 11, and 13).

After acknowledging the technical difficulties, the business suggested modifying and redirecting the focus of the project. However, after exploring other options without finding an alternative way, the public partners assessed that it would require such significant changes to the PCP contract that it would conflict with the original tender and the terms by which the project was awarded the business (phase II interview nos. 8 and 12). As a result, the contract was terminated.

\section{Contagion PCP}

\section{Phase I}

Similar to sterile PCP, the reference group members in contagion PCP and the MDF selected two businesses for phase I based on a limited number of proposals from possible suppliers. The intention was for the two businesses to collaborate with the healthcare professionals in the reference group to develop a more concrete design proposal. However, the reference group members did not have sufficient time to commit to the task (phase I interview with nos. 3 and 4). The leadership in their organization or region appointed them with no hours allocated for the PCP and without further support 
from the management (phase I interview with nos. 6 and 5). As one of them experienced it, other daily tasks and their normal workload meant that they did not actively participate unless called upon to do something specific (phase I interview with no. 3). As a result, exchange of knowledge and learning between the businesses and the healthcare professionals did not take place through regular meetings and interaction as initially planned. However, a strong commitment to the project from the private partners led them to go beyond the reference groups to develop their design proposals. Their own responsibility to ensure input from a broad spectrum of healthcare professionals was clear from the PCP contract and recognized by the businesses themselves (phase I interview with nos. 1, 2, and 12). The businesses used their network outside the project to get the necessary input from doctors, cleaning staff, and nurses at hospitals across the country. Gaining access to other healthcare professionals was easier because of their involvement in the PCP, which provided them with a legitimate point of contact (phase I interview nos. 1 and 2).

By the end of phase I, both businesses succeeded in developing and submitting an updated design proposal for a solution that reduces the risk of contagion in hospital rooms. However, they spent more resources on the proposal than expected to ensure sufficient input beyond the limited interaction with the reference group (phase I interview with nos. 1,2, and 12). Moreover, only two remaining reference group members were left with the responsibility of selecting the most qualified design 
proposal in collaboration with the MDF and the aforementioned law firm, which was a difficult task (phase I interview with nos. 3 and 5). In the end, the MDF and reference group selected one of the proposals to continue to the second phase.

\section{Phase II}

In phase II, the development and testing of a prototype progressed without significant obstacles in contagion PCP, as the main challenges from phase I were addressed early on. Although a new challenge arose in terms of ensuring test facilities, the issue was resolved when additional resources were allocated for this purpose, as mentioned in the analysis of sterile PCP. The prospect of compensation encouraged one of the hospitals represented in the reference group to commit to providing staff and hospital rooms, which became a crucial driver in ensuring progress in the business' further test and development (phase II interview with nos. 2, 5, 6, and 16).

Among key drivers in phase II, the business made progress by ensuring more input from the reference group as well as from other hospitals across the country (phase II interview with nos. 2, 5, 6, and 16). While some of their own staff members and competencies leaving the project was a challenge, they quickly assured new qualifications (phase II interview with nos. 2 and 13). From the public partners' side, there was a stronger representation of key skills and knowledge in the reference group with new members joining, increased support from the participating staff and management of the test hospital, and a renewed commitment among reference group 
members to participate (phase II interview with nos. 2, 6, and 16). Some reference group members continued to experience lack of support from the regional and organizational management as a demotivating factor, along with limited time to participate, as in phase I. However, their own commitment to and feeling of responsibility for the PCP persevered, aided by improved collaborative relationships and an expanded reference group (phase II interview with nos. 3, 4, and 6).

The organization of and collaboration in the reference group was not completely without challenges in phase II. The business' technical and commercial focus conflicted somewhat with the professional integrity of the staff at the involved test facility, causing some collaborative issues and disagreement about the prototype tests. For instance, the business became interested in selling an early version of the prototype, although with significant differences from the agreed PCP solution, which caused some uneasiness and distrust in the reference group (phase I interview with nos. 3, 4, and 6). The technical focus likewise made it difficult for the reference group members to understand the progress reports from the business and hence fully engage in the exchange of knowledge (phase II interview with nos. 2, 3, and 5). Meanwhile, more frequent meetings and open dialogue helped solve these conflicts (phase II interview with nos. 2, $3,4,5$, and 6 ). Both sides agree that the exchange of information improved significantly, allowing for the provision of crucial input for the business in developing the prototype (phase II interview with nos. 2, 3, 4, 5 and 6). 
With regard to phase II outcomes, both the business and the interviewed public participants expect that the development and test of the prototype will succeed within the timeframe. The second phase is still in progress at the time of finishing this evaluation and the technical development is challenging, but the involved parties have so far been satisfied with the progression and test results.

\section{Discussion}

The following sections discuss and compare which structural, collaborative process, and participant factors have conditioned the opposite outcomes across the two PCP projects.

\section{Structural factors}

The analysis shows that resource munificence was a key structural challenge across both phases and for both PCPs. The public reference group members struggled to find time to prioritize the PCP and lack of resources allocated for test facilities became an issue. Although additional funds were found for the purpose of ensuring test facilities, this solution only became beneficial in contagion PCP, where test facilities were already within reach and the development of the prototype on track. In sterile PCP, the lack of time and clarification of responsibility among the public partners continued to constrain progress in both phases. Moreover, the business' technical challenges in developing a prototype ended the project before deciding on suitable test facilities.

The risk sharing and competitive feature of the PCP model proved challenging to the development of new solutions in the Danish case. In phase I, preparatory work by 
the MDF and a law firm helped ensure that the process of selecting businesses in both phases complied with general procurement rules and the PCP model (phase I interview with nos. 15 and 14). In contagion PCP, the PCP framework was not a source of conflict, as the technical development progressed as planned and contractually agreed, aided by a committed reference group, additional resources, and project management. In sterile PCP, technical difficulties in developing the prototype emerged as an unforeseen obstacle that led to cancellation of the contract. The two cases show that it requires careful preparation and completion of the procurement and contract to avoid such risks as state aid issues and violation of the principles of equal treatment in a publicly financed innovation process (European Commission, 2007; Thorgaard, 2013). However, reducing these risks is a challenge, as the final product cannot be specified at the onset of an innovation process and project feasibility is thus not guaranteed. Failure is an unavoidable risk associated with innovation, as the technical obstacles in sterile PCP demonstrate. The question is whether the PCP framework thereby induces risk-averse considerations for the public partner that conflict with the unpredictability of an innovation process and limits collaborative relations. Interviews with some public participants indicate that the business was considered a supplier of a specified solution rather than a development partner (phase II interview with nos. 8 and 10). This perception suggests that sharing of risks and benefits is challenging in practice. 
Moreover, only five proposals from three businesses participated across both PCPs due to a limited number of initial bids (Kammeradvokaten, 2014a;

Kammeradvokaten, 2015a; Kammeradvokaten, 2015b). Only one proposal continued to the second phase for each PCP. The limited number of suppliers made a few of the reference group members question whether the development of prototypes should have been left to the market (phase I interview with nos. 10 and 6). Competition among suppliers and separation from the commercial phase in PCP is meant to ensure participation from the best possible proposals before committing to a large-scale purchase (European Commission, 2007). However, a poorly specified tender or lack of competition can lead to higher costs or a lack of realization of intended quality improvements for the public partner (Carpintero and Petersen, 2014; Rangel and Galende, 2010). The limited number of bids in the Danish case indicates that the possibility of finding the best solution might have been compromised. The decision to cancel the contract in sterile PCP also brought forth retrospective concerns of whether the initial tender was too broad and should have been more specific to ensure feasibility, although a more specified tender could have reduced the innovative purpose (phase II interview with nos. 8 and 10). Other participants emphasized that the demanded solutions might not be developed at all without the PCP (phase I interview with nos. 7 and 13), which supports the purpose of the model (Edquist and Zabala-Iturriagagoitia, 2015). 


\section{Collaborative process}

The structural challenge of insufficient resources for the participation of the public partners had consequences for the collaborative process in terms of the organization of the PCP and the exchange of knowledge. The secondary steering committee, established to oversee the contract and process of both PCPs, did not exist in practice except for one consistent member. Other members left due to job changes, conflicts of interest, and retirement (phase I interview with nos. 13 and 14). By the end of the first phase, the steering committee was abolished, thus leaving the reference group in charge, which consisted of only a few remaining representatives with limited time to participate. As a result, there was likewise limited learning and exchange of knowledge among the public and private participants in both PCP projects.

While the situation improved for contagion PCP in phase II with an expanded and more committed group of public participants that helped drive the development and testing forward, the challenges persevered in sterile PCP. More members were added to the reference group in sterile PCP at the beginning of phase II, but only a few members participated, with limited time to do so. This created an imbalance, where the feedback expectations of the business exceeded the group members' resources and ability to deliver, thus constraining progress in the development and early testing of parts of the proposed solution.

\section{Participants}


With regard to the participants, a key challenge was to ensure commitment among the reference group members to participate actively and collaborate with the businesses, in part due to limited support from their organizational and regional management. This challenge is possibly associated with the lengthy process of the PCP, which makes member continuation difficult. Furthermore, the decision to participate was taken at higher leadership levels in the regional governments, not by the participating hospitals and healthcare professionals themselves (phase I interview with nos. 15 and 14).

The commitment and ownership in sterile PCP continued to decline throughout both phases. Time constraints among the limited core of public reference group members inhibited the learning and exchange of knowledge necessary to develop a prototype. Meanwhile, in contagion PCP, reinforced competencies, improved collaborative relations, and shared governance by the public and private partners in the reference group became key drivers for the development and testing of the prototype.

Finally, the MDF fulfilled an important and perhaps more demanding role than anticipated in both PCPs due to the challenges in the organization and commitment of the reference groups. The MDF project managers kept the process moving forward, coordinating between the partners, solving problems, keeping the few remaining members engaged, and by the end of the first phase recruiting new members with relevant qualifications. However, the realization of a functional prototype hinges on the business' own governance of the development process and its collaboration with the 
public representatives in the reference group. The active presence of a formal project management alone cannot drive or ensure success, as the two projects demonstrate.

\section{Outcomes}

The two projects achieved the intended outcomes in phase I. The businesses developed concrete design proposals within the six months as planned and used these in an updated tender for phase II. However, due to the limited learning and exchange of knowledge in the reference groups in phase I, development of the design proposals was challenging and time consuming. From the public partners' perspective, the selection of businesses was also achieved within the given timeframe, but the result was continuation of only one business for each PCP, thus undermining the competitive mechanism of the PCP model.

In phase II, the two PCP projects resulted in opposite outcomes. In contagion PCP, the development and testing of the prototype is expected to succeed. There are no tangible benefits for the business yet, and commercialization is not a part of the PCP. Nonetheless, the business gained access to key professionals in the hospital sector, expect to sell its first prototype soon after finalizing the project, and hope to establish a new spin-off business for the developed product. For the public participants, concrete benefits are limited in light of the amount of time spent on the PCP, but they developed their network in the field and gained new knowledge on technological trends for use in their respective organizations. 
In sterile PCP, the public partners decided to cancel their PCP contract with the business. With regard to value creation, the benefits are limited and at a more personal level. For the public partners, an interest in keeping up to date on recent technology and for the sake of their resumes made participation worth their while, along with a stronger cross-hospital and regional network. As to the business, the PCP led to ideas for patenting other solutions.

Finally, from the perspective of the MDF, they gained experience with and enhanced skills in public-private collaboration. As an attempt to try out the PCP model for the first time in Denmark, the MDF already used the experiences from the healthcare PCP to improve the design and organization of two subsequent PCPs in other policy sectors (phase I and II interviews with nos. 13 and 14).

Figures 2 and 3 illustrate the analytical results in light of the theoretical framework by comparing which factors were drivers or barriers in the two PCP projects in each phase and with what consequences for outcomes. 
Figure 2 Constraining and driving factors in phase I

$$
+/ \rightarrow \text { driving factors } \quad-/-->\text { constraining factors }
$$

Tender phase I structural factors

Clarification of regulation, PCP model, and criteria for evaluation of proposals $(+)$

Only a few suppliers submitting proposals for phase I (-)

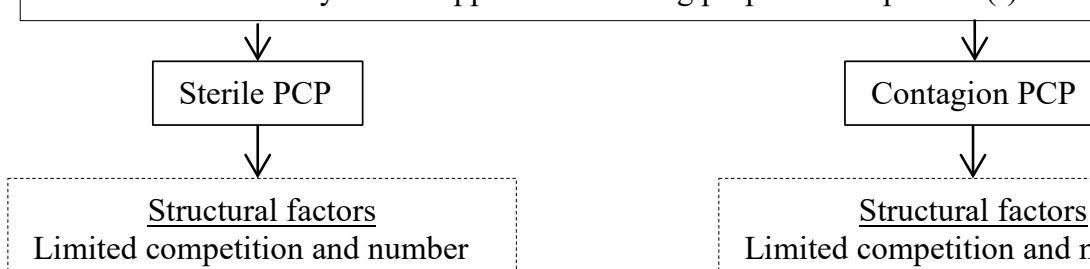

of businesses (-)

Lack of time/resources for public

of businesses (-)

reference group members (-)

Lack of time/resources for public reference group members (-)<smiles>[V]I</smiles>

Collaborative factors

Limited learning and exchange of knowledge in RG (-)

Changes and limited number of healthcare professionals in organization of RG (-)

Limited learning and exchange of knowledge in RG (-)<smiles>[IH][IH]</smiles>

Participant factors

Committed businesses investing time and resources to develop best possible design proposal $(+)$

Lack of regional ownership and RG commitment (-)

Project management by MDF (+)

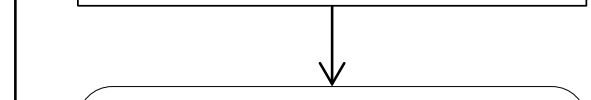

Outcomes

Development of two design proposals

Selection of one design proposal

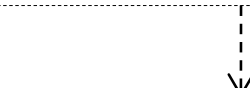

Collaborative factors

Limited learning and exchange of knowledge in RG (-)

Changes and limited number of healthcare professionals in RG (-)

Exchange of knowledge between businesses and healthcare professionals outside of $\mathrm{PCP}(+)$

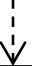

Participant factors

Committed businesses investing time and resources to develop best possible design proposal $(+)$

Lack of regional ownership and RG commitment (-)

Project management by MDF (+)

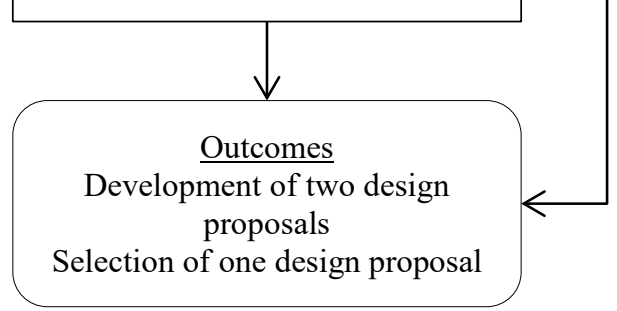

$\mathrm{RG}=$ reference group 
Figure 3 Constraining and driving factors in phase II

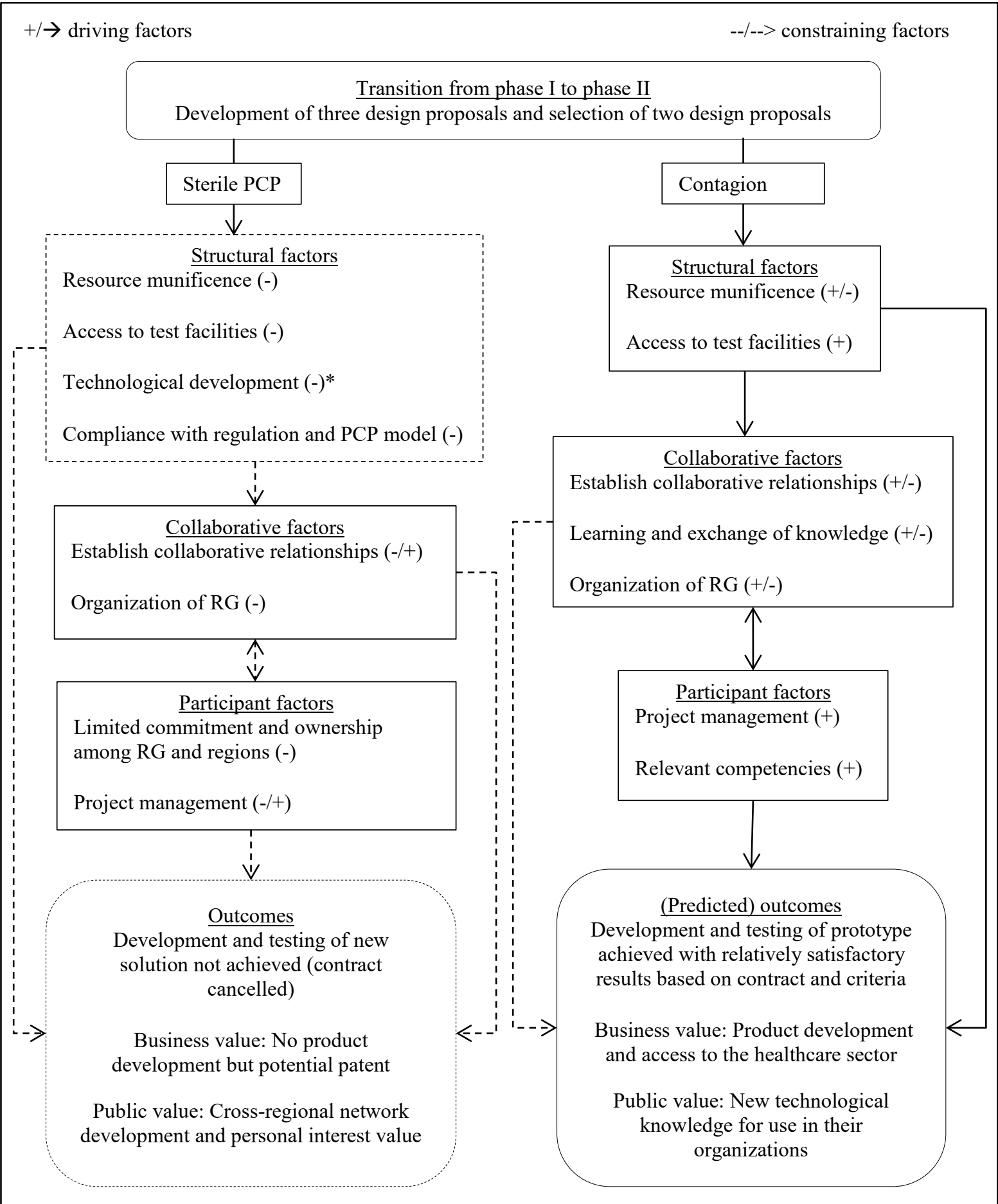

$\mathrm{RG}=$ reference group

*Feasibility of the proposed technological development was not a part of the program theory, but is included in the results as a structural challenge, as it relates to the PCP contract and the framework for the development process. 


\section{Conclusion}

The first systematic and theory-based evaluation of national experiences with PCP shows how the same framework for developing new solutions resulted in opposite outcomes in the Danish case. In the first phase, both projects were constrained by lack of resources, declining commitment among participants, and thus limited learning and exchange of knowledge. These challenges were to a large extent solved later on in one of the projects. Allocation of additional resources for testing facilities, focused project management by the business, and a stronger group of healthcare professionals with the necessary competencies and commitment contributed to the development and testing of a prototype. Meanwhile, in the other project, limited resources, exchange of knowledge, commitment among participants, and governance by the private partner constrained the development of new solutions. Difficulties in realizing the technical aspect of the more innovative part of the design proposal became the crucial obstacle that eventually led to cancellation of the contract. In this case, the PCP model cannot accommodate significant changes to the agreed solution during the innovation process. Finally, both projects experienced challenges in implementing the competitive feature of PCP as demonstrated by limited bids and business participants in the different phases.

The involved businesses remained positive about PCP as a model for publicprivate innovation. To them, the advantage is that PCP entails a pre-agreed purchase of research and development, along with clarification of state aid issues and procurement 
rules. This reduces the risks of disqualification in case of a subsequent purchase. Moreover, the PCP resulted in product development, market access, and commercial aspirations for the business in the project that successfully developed and tested a prototype.

The article offers several contributions to the growing literature on public procurement for innovation. First, by using a program theory approach to analyze the Danish PCP projects, the article provides the first systematic and theory-based evaluation of national experiences with the PCP model known to the author. The broader contribution lies in the lessons learned from the Danish case and demonstrating the use of program theory to identify key drivers and barriers in using PCP to stimulate innovation. For practitioners working with PCP, the study demonstrates the importance of ensuring sufficient resources for testing and exchange of knowledge between public and private participants. Prioritizing these two drivers can enhance the development of a solution that corresponds to the public partners' needs. Without committed participants and a mediating project management to drive the process forward, challenges quickly arise or become difficult to overcome

Overall, this study has taken the first step to embark on more systematic analyses of recent innovation policy instruments. To address both the challenges and the potential of novel forms of innovation procurement, we need further research and empirical studies of national experiences. Specifically, the results of this study indicates 
that the PCP model induces a risk averse behavior on the part of the public partner that conflicts with the innovation and collaboration process. The Danish case furthermore indicates that PCP is a resource demanding model that is perhaps more suitable for cross-country or national projects with more public actors and potential suppliers to ensure sufficient competition. Comparative studies of the growing number of PCP projects within the EU and conceptual research into the theoretical underpinnings of the model can provide additional evidence and insights into the findings from the Danish case and the use of the PCP model.

\section{Notes}

1. To preserve the promised anonymity of the interviewees, no details are given regarding their identity and they are referred to by numbers in the analysis.

2. NVivo 11 was used to analyze all data.

3. The evaluation is part of a larger research project that was completed before the end of phase II.

\section{References}

Andrews R and Entwistle T (2015) Public-private partnerships, management capacity and public service efficiency. Policy and Politics 43 (2): 273-290. 
Askfors $\mathrm{Y}$ and Fornstedt $\mathrm{H}$ (2018) The clash of managerial and professional logics in public procurement for innovation in the health-care sector. Scandinavian Journal of Management 34: 78-90

Carpintero S and Petersen OH (2014) PPP projects in transport: evidence from light rail projects in spain. Public Money \& Management 34 (1): 43-50

Chen HT and Turner NC (2012) Formal theory versus stakeholder theory: new insights from a tobacco-focused prevention program evaluation. American Journal of Evaluation 33(3): 395-413.

Chicot J and Matt M (2017) Public procurement of innovation: a review of rationales, designs, and contributions to grand challenges. Science and Public Policy (e-pub ahead of print): $1-13$.

Edelenbos $\mathrm{J}$ and Klijn EH (2007) Trust in complex decision-making networks: a theoretical and empirical exploration. Administration \& Society 39(1): 25-50.

Edelenbos J, Klijn EH and Steijn B (2011) Managers in governance networks: how to reach good outcomes? International Public Management Journal 14(4): 420-444.

Edler J and Georghiou L (2007) Public procurement and innovation: resurrecting the demand side. Research Policy 36(7): 949-963. 
Edquist C and Hommen L (1999) Systems of innovation: theory and policy for the demand side. Technology in Society 21(1): 63-79.

Edquist C and Zabala-Iturriagagoitia JM (2012) Public procurement for innovation as mission-oriented innovation policy. Research Policy 41(10): 1757-1769.

Edquist C and Zabala-Iturriagagoitia JM (2015). Pre-commercial procurement: a demand or supply policy instrument in relation to innovation? R\&D Management 45(2): 147-160.

European Commission (2007) Pre-commercial procurement: driving innovation to ensure sustainable high quality public services in Europe. Communication from the Commission to the European Parliament, the Council, the European Economic and Social Committee and the Committee of the Regions. Belgium: European Commission.

European Commission (2017) Innovation Procurement. Available at: $\underline{\text { https://ec.europa.eu/digital-single-market/en/innovation-procurement }}$ (accessed 16 January 2018).

Funnel SC and Rogers PJ (2011) Purposeful Program Theory: Effective use of Theories of Change and Logic Models. San Francisco, CA: Jossey-Bass.

Huxham C and Vangen S (2000) Leadership in the shaping and implementation of collaboration agendas: how things happen in a (not quite) joined-up world. Academy of Management Journal 43(6): 1159-1175. 
Kalvet T and Lember V (2010) Risk management in public procurement for innovation: the case of Nordic-Baltic Sea cities. Innovation: The European Journal of Social Science Research 23(3): 241-262.

Kammeradvokaten (2014a) Konkurrencebetingelser for Prcekommercielt Indkøb af udvikling af nye, innovative løsninger til reduktion af smittespredning. Copenhagen: Kammeradvokaten.

Kammeradvokaten (2014b) Konkurrencebetingelser for Prokommercielt Indkøb af udvikling af nye, innovative robotløsninger til sterilcentraler. Copenhagen: Kammeradvokaten.

Kammeradvokaten (2015a) Konkurrencebetingelser for afgivelse af tilbud på fase $2 i$ Prakommercielt Indkøb af udvikling af nye, innovative robotløsninger til sterilcentraler. Copenhagen: Kammeradvokaten.

Kammeradvokaten (2015b) Konkurrencebetingelser for afgivelse af tilbud på fase $2 i$ prokommercielt indkøb af udvikling af nye, innovative løsninger til reduktion af smittespredning. Copenhagen: Kammeradvokaten.

Kenis P and Provan KG (2009) Towards an exogenous theory of public network performance. Public Administration 87(3): 440-456. 
Klijn EH, Sierra V, Ysa T, Berman E, Edelenbos J and Chen DY (2016) The influence of trust on network performance in Taiwan, Spain, and the Netherlands: a cross-country comparison. International Public Management Journal 19(1): 111-139.

Klijn EH, Steijn B and Edelenbos J (2010) The impact of network management on outcomes in governance networks. Public Administration 88(4): 1063-1082.

Klijn EH, Ysa T, Sierra V, Berman E, Edelenbos J and Chen DY (2015) The influence of network management and complexity on network performance in Taiwan, Spain and the Netherlands. Public Management Review 17(5): 736-764.

Lember V, Kalvet T and Kattel R (2011) Public sector innovation at the urban level: the case of public procurement. In: Bekkers V, Edelenbos J and Steijn B (eds) Innovation in the Public Sector: Linking Capacity and Leadership. UK: Palgrave Macmillian, pp. 82104.

Lundvall BA (ed) (2010) National Systems of Innovation. Toward a Theory of Innovation and Interactive Learning. London: Anthem Press.

Miles MB and Huberman AM (1994) Qualitative Data Analysis: An Expanded Sourcebook. Thousand Oaks, CA: Sage.

Nohrstedt D (2016) Explaining mobilization and performance of collaborations in routine emergency management. Administration \& Society 48 (2): 135-162. 
Petersen OH, Lember V, Scherrer W and Ågren R (2016) The role of private actors in public sector innovation. In: Torfing $\mathrm{J}$ and Triantafillou $\mathrm{P}$ (eds) Enhancing Public Innovation by Transforming Public Governance. Cambridge, UK: Cambridge University Press, pp.197-214.

Pitsis TS (2015) Get strategic: on the strangeness of theory and value. Journal of Strategic Contracting and Negotiation 1(2): 104-110.

Provan KG and Kenis P (2008) Modes of network governance: structure, management, and effectiveness. Journal of Public Administration Research and Theory 18(2): 229252.

Rainville A (2017) Standards in green public procurement - A framework to enhance innovation. Journal of Cleaner Production 167: 1029-1037.

Raiteri E (2018) A time to nourish? Evaluating the impact of public procurement on technological generality through patent data. Research Policy 47: 936-952.

Rangel T and Galende J (2010) Innovation in public-private partnerships (PPPs): the spanish case of highway concessions. Public Money \& Management 30 (1): 49-54.

Raab J, Mannak RS and Cambre B (2015) Combining structure, governance, and context: a configurational approach to network effectiveness. Journal of Public Administration Research and Theory 25(2): 479-511. 
Rolfstam M (2009) Public procurement as an innovation policy tool: the role of institutions. Science and Public Policy 36(5): 349-360.

Rolfstam M and Petersen OH (2014) Public procurement of innovation policy: the case of Denmark. In: Lember V, Kattel R and Kalvet T (eds) Public Procurement, Innovation and Policy. International Perspectives. London: Springer, pp.109-126.

Smith G, Sochor J and Karlsson ICM (2018) Public-private innovation: barriers in the case of mobility as a service in West Sweden. Public management Review (e-pub ahead of print).

Steijn B, Klijn EH and Edelenbos J (2011) Public private partnerships: added value by organizational form or management? Public Administration 89(4): 1235-1252.

The Danish Market Development Fund (2014a) Behovsbeskrivelse (Sterile PCP). Bilag 1. Copenhagen: The Danish Market Development Fund.

The Danish Market Development Fund (2014b) Behovsbeskrivelse (Contagion PCP). Bilag 1. Copenhagen: The Danish Market Development Fund.

The Danish Market Development Fund (2014c) Innovative offentlige indkøb. Kort introduktion. Copenhagen: The Danish Market Development Fund.

The Danish Market Development Fund (2014d) Samarbejdsorganisation. Bilag 3. Copenhagen: The Danish Market Development Fund. 
The Danish Market Development Fund (2014e) Udskillelse af leverandører ved overgang til fase 2. Bilag 5. Copenhagen: Danish Market Development Fund.

Timmer I (2016) Changing roles of legal: on the impact of innovations on the role of legal professionals and legal departments in contracting practice. Journal of Strategic Contracting and Negotiation 2(1-2): 34-47.

Uyarra E, Flanagan K, Magro E and Zabala-Iturriagagoitia JM (2017) Anchoring the innovation impacts of public procurement to place: The role of conversations. Environment and Planning C: Politics and Space 35(5): 828-848.

Uyarra E, Edler J, Garcia-Estevez J, Georghiou L and Yeow J (2014) Barriers to innovation through public procurement: a supplier perspective. Technovation 34(10): $631-645$.

Vedung E (2009) Public Policy and Program Evaluation. (4th ed) New Jersey: Transaction Publishers. 